\title{
Information Communication Technology (ICT) in Public Sector Banks: Bane or Boon?
}

\author{
Gauri Prabhu, Rohit Alandikar
}

\begin{abstract}
ICT has occupied almost every single vertical of human endeavour. For the meticulous services in banks, it has well equipped with the ICT. It increases an efficacy and usefulness of services tendered to the customers, and boosts business procedures, directorial decisions, and joint ventures, which underpins their abilities rapidly of altering and emerging economies with the help of ICT. The present paper emphasises the sways and drifts of ICTs on the banking industry of in this ear of technology. Market structure, innovation, productivity, and value chain these are the four dynamics which used for touchstone in the banking industry. Case studies of computer platform exercised selected Indian banks were considered for a clear conversant implication.
\end{abstract}

Keywords - Banking, ICT, Innovation, Economic growth, Productivity.

\section{INTRODUCTION}

The competitive advantage and rating of an enterprise are now depending on its ICT infrastructural enlists. It is the strong gesture of the standing of ICT for business formations and its growth. Banks are very precise in adaptation new tidings like communication technology in order to magnify the efficacy and niftiness of services avail to the clienteles, corporate expansions, and to enhance management decision making and best collaborations. It is required supports in bolstering their viable places in rapidly evolving economies. "Ecological, organizational along with technological reasons are behind extremely competitive business milieu in which end consumers are at the." [1] Additionally, the aspects which mentioned here can modified, occasionally erratically. Consequently, the development of any establishment is knotted to retaining valued customers, enlightening output, costs cutting, cumulative market share and availing frequent organizational retort. ICT considers as a foremost point for handling with these subjects. As the leap of modification and the step of ambiguity in existing competitive milieu are fast-tracking geometrically, organizations are working under growing burdens of extra production, using the same, limited and fixed resources, in order to achieve (or even merely to survive) in this active world. Companies tend to apply old-style deeds like dropping costs. Instead of this if they commence advanced actions like structural improvement or modifying processes and endlessly reviewing competitive approaches. ICT has the capacity and surfaces as a main component to move all processes related with current banking practices.
Routines activities like preparing payroll and entries of the order, to planned activities such as the attainment of a company. According to the rostrum of ICT, a number of research works have been procreated in the banking industry. The assessment of response of the clients of Indian banks to the acceptance of ICT was described. In [3], a technical model that to determine the sway of ICT on the Indian banking industry as a function of banking reforms was projected. " Few scales for assessing the effect of ICT in the banking industry were charted in [4].These yardsticks will be used to gauge the impact of ICT on the Indian banking sectors.

\section{Banking Industry in India}

Indian banking is considered as a lifeline not only for the nation but also individuals. Banking supported to evolve the luminous segments of the economy and lead in a fresh advancement on the Indian prospect. The banking sector has rendered the optimisms and objectives of individuals into certainty. Hence, for this, it has had to govern giant hard ground, bear the blots of external law and the wrenches of partition. In current scenario, Indian banks assuredly stand with global up-to-the-minute banks. Before the 20th century, treasury or money loaning at a high rate of interest, was in custom and broadly rampant in rural parts of India.

Expansion of Cooperative drives and easy access of Joint stock banks have betrothed in a large portion of business from the controls of the Indian cash creditor, who although yet happen to be present today, but vanished their dark sides. While going through the transition of Indian Banking System and Cooperative banks which subsist simultaneously with commercial banks and perform an additional part in facilitating need grounded finance notably for agricultural and agriculture-based manoeuvres comprising milk, hatchery, individual finance, farming, cattle etc. along with few miscellaneous industries and self-employment determined practices. Formerly, co-operative banks are overseen by the particular co-operative acts of corresponding state governments. Since, 1st March 1966, just after the modification of Banking Regulation Act 1949, RBI coming in the scene for structuring the banks. The Reserve Bank offers licensing to the banks and its branches. RBI also controls state co-operative banks' credit limits, primary co-operative banks for backing SSI units.

General Bank of India coming into presence in 1786 and followed by Bank of Hindustan after Indian Banking initiated in the first decade of $18^{\text {th }}$ century. These banks no more in function. The government of India instituted three presidency banks in India thereafter. The first being the "Bank of Bengal", in 1809.

Revised Manuscript Received on February 06, 2020.

Dr. Gauri Prabhu, Associate Professor in AISSMS Institute of Management, Pune, India.

Prof. Rohit Alandikar, Assistant Professor,at Modern Institute of Business Management, Shivajinagar Pune, India. 
This was followed by were presidency bank, viz., the "Bank of Bombay" founded in 1840 and the "Bank of Madras" founded in 1843. In 1920, as per the "Imperial Bank of India Act", three of the presidency banks were subsequently combined into the "Imperial Bank of India" (IBI) - which is currently identified as the "State Bank of India". Overseas banks like "Credit Lyonnais" began their Calcutta operations just after few decades in 1850s. At this point, mainly because of the trade by British Empire, Calcutta flourished as the most vigorous trading port, and the result of which banking functions rooted deeply and prospered soon. The very first entirely Indian owned bank, which was founded in 1865, was "Allahabad Bank". By the 1900s, the market extended with the establishment of several banks like "Punjab National Bank" founded in 1895 in Lahore and "Bank of India. " was founded in 1906, at Mumbai, Both of these banks were commenced under private ownership.

Initially, from 1935, "Reserve Bank of India" is regulating the Indian banking sector. In 1947,Post independence, "Reserve Bank" turns out to be nationalized and possessed wide authorities. The banking establishments enlarge gradually and innovation, deregulation, along with technological up-gradation. The systems turned multifaceted and critical to uphold stability between efficacy and firmness.In the past 30 years, due to reforms in financial sectors, nationalization had witnessed great changes in the financial sectors also in the banking industry. The banks can achieve new face only when it sheds old-style activities and have been adopting innovating, improving services to provide evolving requirements of clients. Banks drafted own strategies to gain market. Technology used in banking sectors growing rapidly and it has provided substantial lessening in transaction costs; simplify better diversification of portfolio and enrichments in delivery of credit. Provident policies and norms, along with the global standards, and are set for encouraging and enriching the competencies of banks. The procedure of developing standard strengthened with actions in the related zones of asset rebuilding, recovery, convergence, mass banking, consolidation etc. Regardless of this noteworthy development, various genuine issues have occurred and reflecting in a weakening in output and attrition of the effectiveness of the banking industry. It has been declining in the excellence of credit portfolio which, directly distresses bank's enhancement of capital funds and income generation. Ultimately, insufficiency of capital has been gone together with scantiness of credit loss requirements which ensuing into the contrary impact on the faith of the depositors and investors. Therefore, the Government, formed "Narasimham Committee" to take care of the issues and acclaim preventative measures to improve financial system. "Narasimham Committee" put forward some recommendations which were accepted by the Government has given rise in modification of previously immensely well-organized and bureaucratized banking system into highly competitive and market driven one.

The rapid growth and change of banking sectors has not been without its wrenches. The banking industry is seizing a novel look with cumulative competition from other financing options too. This competition spreads wide, from national to global level. The functioning of banks has been changed in India and anticipated to endure a deep modification in next few years.

Various upcoming private banks and financing sector came into existence and spread with focus to achieve higher targets. Retail banking also emerged emerging together. The current banks have wide geographic span and branch network whereas the private banks have the thump of capital, slender workforces' module, the knowledge in evolving financial offers and usage of up-to-date technology. Steady non suitable parameter that is being accompanied in motivating the competition would also enable to eliminate falsifying mutually valuable associations, which would slowly improve the quality and content of banking. In India, the banks will offers a good account of result in the concluding phase. Within next two decades, the collaborative attempts of co-operative banks, regional and rural banks along with progress in banking institutions are predictable to provide passable number of functioning retail outlets to achieve the evolving client experience. The banking system has also influenced by technological and electronic era which leads to fast electronic fund transfer through ATM \& net banking. Though, the advancement of electronic banking has also created risks of frauds such as data security, integrity and hacking, which demanded up-to-date innovative methods of risk management. Mutually cooperative banks play significant part of abundant financial structures. In various countries, they are among the major financial institutions. Therefore, in terms of total banking sector, the market share of cooperative banks assets amplified from about $9 \%$ to $14 \%$ in just two decades. 


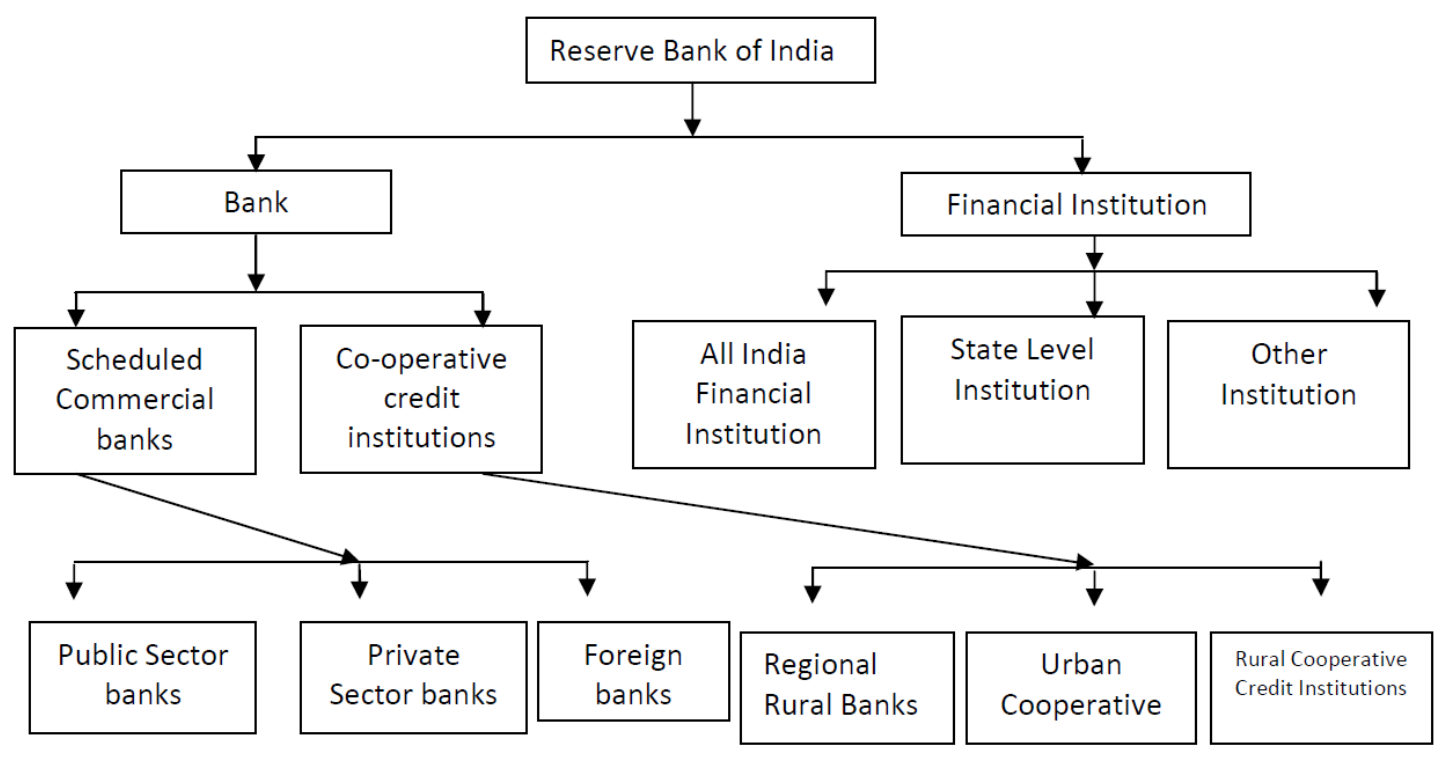

\section{RESEARCH METHODOLOGY}

The major aim of the current study aimed at understanding the level of use of ICT, its infrastructures and influences on current customer service; perpetually regulates evolution of banks. ICT is a growth enabler with the range of deployment by banks and customers' judgement of its consequences from the base of the research. A random sampling technique was used for the current research. Google survey forms were used for the customers in the selected banks. On the basis of adequate branch networks, four commercial banks were selected for the research.

A total of 500 survey forms sent online out of which 300 were considered for research. Hence the response rate counted as $60 \%$.

Four banks considered were 1. "State bank of India" 2. "Bank of Baroda"; 3. "Bank of Maharashtra"; 4. "Central bank of India". The questionnaire was designed to test the responses which were measured on a 5 pointer Likert - type rating, where strongly agree $(\mathrm{SA})=5 ;$ Agree $(\mathrm{A})=4$; Neutral $(\mathrm{N})=3$; Disagree $=2$; Strongly Disagree $=1$.

The primary extents of the banks and the influence of ICT have serious consequences which comprise: market structure, productivity, value chain, characteristics and novelty dynamics.

\section{A. Impact of ICT on Productivity}

Table 1. Effect of ICT on Productivity

\begin{tabular}{|l|l|l|l|l|l|}
\hline Question & SA & A & N & D & SD \\
\hline Computers impact tellers working efficiency & 40.0 & 45.0 & 5.5 & 9.1 & 0 \\
\hline Banks needs to connect easily to end user & 5.10 & 29.0 & 11.0 & 8.0 & 1.0 \\
\hline
\end{tabular}

\section{B. Impact of ICT on Innovation}

A technological transformation includes the enormous transmission of ICT denotes stimulating instance for an analysis, related to bank's revolutionary approaches. For example, it is said that "Industry leaders frequently reject
The study showed that ICT has positive effect on productivity like labour productivity and total factor productivity. ICT persuaded efficiency which differs deliberately among sectors and countries. The major segment of banks is ICT which possess the prime productivity growth as a result. Table 1 indicates the effect of "ICT on the productivity" of the banks as apparent by the customers. About $85.4 \%$ of the respondents feel that due to ICT the cashiers become more productive. ICT infrastructure like computers and related peripherals streamlined the duty of upholding customers' required data and counting money to effective transaction. In other words a cashier can empowers to serve more customers per day with the help of ICT. ICT would help to the banks which have massive staff strength and huge infrastructure. However, among the selected samples, about $80 \%$ of the sample, agree that the bank required to mend its services. This is the signal which indicating the scenario that ICT investment does not directed to productivity but to growth. It actually rests on how the technology is adopted and implemented in business procedures, i.e. on a company's proficiency to transmute its routine work processes and business with the help of ICT. Thus, it is prerequisite by the banks to manage the proper upsurge ICT funds with complementary investment in human capital; working performs, and firm reformation to heighten its influence on output.

vital inventions and hinder them from entering in market" $[8,9]$. Tactical businesses normally utilise and exploit these chances. "New technology is often introduced to new entrants or applicants. This can test officials and drive them out of the market." [10]. It was the situation that competed in the Indian

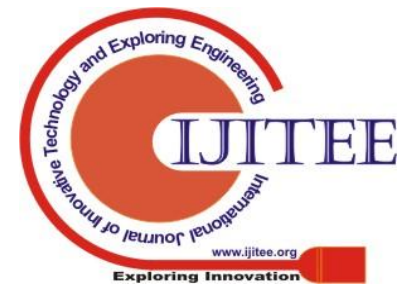


banking sector with the advent of latest banks that offered cutting-edge products and services to their customers. Innovation for these reference intentions to lessen the rate of banks operations while simpler transaction and more convenient procedures. Among the samples, about $67.5 \%$ of the respondents feel that that the amount the bank charges on transaction is not justified. For diminishing the cost of banking operations, banks urged to invent innovative products for the customer in the form of abridged the charges. Among the samples, about $65 \%$ of the respondents from the samples like bank have shared the information update through SMS and also email alerts. This ultimately increases customer loyalty and assurance. Among the samples, $78 \%$ of those interviewed mentioned that they favour to use the ATM instead of entering into the bank physically. This is due to wide utilization of ATMs and has fortified the use of ATM. Thus, banks can boost the usage of other ICT to promote cashless banking.

Table 2 Impact of ICT on Innovation

\begin{tabular}{|l|c|c|c|c|c|}
\hline Question & SA & A & N & D & SD \\
\hline I feel transaction charge is okay on online transactions & 10.0 & 10.0 & 12.5 & 40.0 & 27.5 \\
\hline I think SMS and email alerts are very useful & 32.0 & 29.0 & 11.0 & 8.0 & 1.0 \\
\hline I prefer ATM than physical withdrawal of cash & 48.0 & 30.0 & 9.0 & 7.0 & 6.0 \\
\hline
\end{tabular}

\section{Impact on Market Structure}

The cost structure of companies permitted changes of usage and innovations in ICT. Hence, it can be stated that modernizations have a noteworthy impression on the market edifice and companies' utilities. Fundamental or basic alterations in technology predictably draw to occurrence of innovative products or modification in the existing products or its production processes. "In either case, companies face huge chances of uncertainty regarding future demand or cost of service delivery." [5]. "Furthermore, mean times of technological change, mergers reflect the process of assets reallocation toward more efficient firms." [11]. The blends and the unions that were recently demonstrated in the Indian banking sectors were basically an output of the alliance exercise of 2004 and the technological modification that started and applied in the industry.
The change which induces firms in Technology adopt and implement new means of production and, subsequently, to restructure its assets. In case a company forsake to rectify within, it will possibly vanish from the industry and its belongings will be restructured externally. "Advanced technology spreads faster if such asset reallocation works smoothly." [12]. Technological modification that has greatly revolutionized the banking sector considered as the offering of ICT. Below 'Table 3' shows that $75 \%$ of the respondents agree and stated that the quality of service rendered by the banks have improved. This is needed for the bank to preserve and hold its customer as well as to attract potential new customers. Among the total samples, $79 \%$ of the customers sample agreed that they enjoy quick and prompt service for which $87 \%$ of the respondents are willing to endorse the bank to others.

Table 3: Impact of ICT on Market Structure

\begin{tabular}{|l|c|c|c|c|c|}
\hline Question & SA & A & N & D & ND \\
\hline The quality of facility has upgraded in this bank & 50 & 25 & 10 & 14 & 1 \\
\hline I enjoy fast, efficient and prompt service & 49 & 30 & 11 & 11 & 0 \\
\hline I can recommend this bank to someone & 55 & 32 & 8 & 5 & 0 \\
\hline
\end{tabular}

\section{Impact on Sector Value Chain}

Empirical findings advocate that "Some of the key impacts of ICT usage resulted into organizational changes and hence the redefining of organizational boundaries." [12]. Thus, it is applicable to evaluate that the transmission of ICT in the banking industry had any influence on the rearrangement process. The sway on value chain replicates in determining steady margins and altering the assemblages of value chains are huge. Table 4 indicates that only $47 \%$ of the sample size among the whole sample agreed that add on services/special accounts boost the customers to support the respective bank. This perception of bank customer needs to be corrected by extensive circulation about the value-added services so as to balance the impression of ICT. A bank has huge number of branches which enriches the imprints and standard of positioning of ICT.

Table 4 Impact of ICT on Banking Sector Value Chain

\begin{tabular}{|l|c|c|c|c|c|}
\hline Question & SA & A & N & D & ND \\
\hline $\begin{array}{l}\text { Distinct services/account types encourage me to } \\
\text { patronize this bank }\end{array}$ & 27 & 20 & 5 & 28 & 20 \\
\hline $\begin{array}{l}\text { The number of branches this bank has motivated me } \\
\text { to chose it }\end{array}$ & 30 & 35 & 5 & 13 & 17 \\
\hline
\end{tabular}




\section{III.DISCUSSIONS ON FINDINGS AND CONCLUSION}

The present research has certain outcomes which specify that for the efficiency and growth in the banking industry investment in an ICT system and infrastructures is a crucial factor. By investing more in ICT in banking sector, results in accelerated growth. ICT facilitates the engagement of high and medium skilled resources for reducing the efforts. It is considered as positive impact on labour output in the banking industry. The current research carried out some case studies which reflect the following outcomes - ICT empowers banks to avail a broad variety of services to their customers, branch activity management, regulate to market demands, competition, and government regulations along with the policies.

Banks need to draw out innovative practises to reach the unbanked by validating investment on ICT to attracts the customers. By using the non-bank means; a process that will comprise investment in innovative ICT tools is to upsurge the geographical outreach of the financial system. Banking industry need the growth plan to scale up to their business setting, competitive ratio and dynamic constant solutions which is required to create a clear distinction in the market quickly. An essential ability of flexibility and scalability provides the bank industry with a competitive advantage to remain frontward and offer first-hand and improved customer centric practices to delight their customers. However, the use ICT does not lead to increase productivity at firm-level. It hinges and guides on the usage of how the technological infrastructure is actually executed in business processes, i.e. on a company's capability to innovate its work practices and business routines with the help of ICT. Thus, only if ICT investment is paired with the investment in human resources, working practices, , and stable restructuring will it have an impact on work performance and eventually on outputs. The finding of the current study specifies that basic ICT infrastructures in banking industry such as ATMs ,computer and peripherals, and local area networks are critical to the functions of banks. However, the studies in this research denote that to catch the constantly increasing demands of customers and to stay competitive in a evolving economy, a robust, scalable and flexible and ICT solution is important.

\section{REFERENCES}

1. Efraim Turban, Dorothy Leidner, Ephraim McLean, James Wetherbe, "Information Technology for Management: Transforming Organizations in the Digital Economy", 3rd edit., John Wiley \& Sons, Inc., pp.10-15. ISBN 978-0-471-78712-9.

2. Akinlolu Agboola, "Information And communication Technology (ICT) In Banking Operations in Nigeria -An Evaluation Of Recent Experiences", African Journal of Public administration and Management Vol XVIII, No. 1 January 2007.

3. Zhao, T., Casu, B. and Ferrari, A. "Deregulation and Productivity Growth: A Study of The Indian Commercial Banking Industry". International Journal of Business Performance Management, 10(4): 318-343, 2008

4. Goyal, K. A. and Joshi, V. "Mergers in Banking Industry of India: Some Emerging Issues". Asian Journal of Business and Management Sciences, 1(2): 157-165, 2011a.

5. Fernando, A. C. "Business Environment". Noida: Dorling Kindersley (India) Pvt. Ltd. (2011), pp. 549-553.
6. Clark, M. "Modelling the Impact of Customer-Employee Relationships on Customer Retention Rates in a Major UK Retail Bank". Management Decision, 35(4): 293-301, 1997.

7. Clark, M. "The Relationship between Employees' Perceptions of Organizational Climate and Customer Retention Rates in a Major UK Retail Bank". Journal of Strategic Marketing, 10(2):93-113, 2002

8. 8. Arend, R. J, "Emergence of entrepreneurs following exogenous technological change", Strategic Management Journal, Vol. 20, pp. 31-47, 1999

9. Clayton M. Christensen, "The Innovator's Dilemma: when new technologies cause great firms to fail" Harvard Business School Press Boston, 1997

10. Peter Yannopoulos," Defensive and Offensive Strategies for Market Success ", International Journal of Business and Social Science Vol. 2 No. 13 [Special Issue - July 2011

11. Bartel, A. P. "Human Resource Management and Organizational Performance: Evidence from Retail Banking". Industrial and Labor Relations Review, 57(2): 181-203, 2004.

12. Dev, S. M. "Financial Inclusion: Issues and Challenges". Economic \& Political Weekly, 41(41): 2006.

13. Sekaran, U. "Paths to the job satisfaction of bank employees". Journal of Organizational Behavior, 10(4): 347-359, 1989.

14. Mitchell, T R., Holtom, B. C., Lee, T. W. and Graske, T. "How to Keep Your Best Employees: Developing an Effective Retention Policy". The Academy of Management Executive, 15(4): 96-109, 2001

15. Jovanovic, B. and Rousseau, P. L. "General Purpose Technologies", Handbook of Economic Growth edited by Philippe Aghion \& Steven Durlauf Edition 1, Vol. 1, No.1, Elsevier.

16. Brynjolfsson E., Malone T. W., Gurbaxani V., and Kambil A. "Does Information Technology Lead to Smaller Firms?", Management Science, Vol. 40, No. 12, pp. 1628-1644, 1994.

\section{AUTHORS PROFILE}

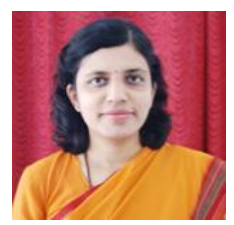

Dr Gauri Prabhu is a Ph.D in Finance and a Research guide of Savitribai Phule Pune University. She has done MBA, M.Com, SET and DCA. Her experience includes 17 years in academics and 5 years in industry. Dr Gauri Prabhu has presented around 21 research papers at national and international conferences and at IIM Ahmedabad, IIM Bangalore. Her papers have been published in reputed journals and UGC journals. She has authored a book on "Startup and New Venture Management".

At present, Dr Gauri Prabhu is working as Associate Professor in AISSMS Institute of Management, Pune. She is teaching subjects like Managerial Accounting, Financial Management, Startup New Venture Management. She is a member of Pune Management Association.

Dr Gauri Prabhu was awarded the prestigious Dewang Mehta National Education Award for "Best Professor in Finance".

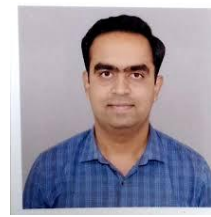

Prof. Rohit Alandikar, Assistant Professor,at Modern Institute of Business Management

Shivajinagar Pune 05

He has more than 5 years (Previously working in Indira College of commerce and science).He has Qualification as BBM (IB), MBA.He is specialized in Finance and Marketing. 